https://doi.org/10.18485/iipe_60nam.2021.ch22

\title{
2021, THE NON-ALIGNED MOVEMENT IN THE GLOBAL ARENA: GEOPOLITICAL CONSIDERATIONS AND REAFFIRMED NEEDS IN A MULTIPOLAR SETTING
}

\author{
István TARRÓSY ${ }^{1}$
}

\begin{abstract}
This chapter offers an overview of the Non-Aligned Movement (NAM) in the modern global system using Dominique Moïsi's innovative geopolitical approach of emotions. It looks at how the place and role of the NAM have been changing in international relations since its foundations were laid down at the conferences of Bandung (1955) and Belgrade (1961). The analysis presents a number of questions for further debate over the changing global order and the issues and approaches represented by the NAM within it, centred around such key questions as human security and "development as freedom" along the theory of Amartya Sen. It deals with the $18^{\text {th }}$ NAM Summit held in Baku, Azerbaijan, and draws upon several of the key statements of its final document in an effort to confirm the refined relevance of the Movement in the $21^{\text {st }}$ century.

Key words: interpolar, multipolar, geopolitics, spirits of Bandung and Belgrade, New Asian-African Strategic Partnership, emotions, human security.
\end{abstract}

\section{The NAM and the global context on Moïsi's geopolitical map of emotions}

The significance of the Bandung Conference of 1955 in global history is pivotal from a number of angles. In the bipolar setting of the Cold War, this milestone Asian-African conference provided a common ground for

\footnotetext{
${ }^{1}$ Associate Professor and Director, Department of Political Science and International Studies, Africa Research Centre, University of Pécs, Hungary.

E-mail: tarrosy.istvan@pte.hu
} 
aggravation of ideas and hopes also stemming from "a culmination of connections and relationships that had crossed the Indian Ocean world for centuries" (Lee, 2010, p. 10). The hopes and aspirations articulated by the twenty-nine Asian and African countries were derived from the fact that, according to the words of President Soekarno's opening speech, "For many generations, our peoples have been the voiceless ones in the world [...] the un-regarded, the peoples for whom decisions were made by others whose interests were paramount, the peoples who lived in poverty and humiliation." (Soekarno in Kahin, 1955, p. 41). In his 2010 book, French scholar of geopolitics Dominique Moïsi pointed exactly in this direction in search of a better understanding of our international system, underscoring that, today, "quests for identity by peoples uncertain of who they are, their place in the world, and their prospects for a meaningful future have replaced ideology as the motor of history, with the consequence that emotions matter more than ever" (Moïsi, 2010, p. 4). He proposed an innovative geopolitical mapping of our global world in an emotional way, clearly acknowledging the difficulty to analyse and categorise countries according to his three basic types, i.e., primary emotions of fear, hope, and humiliation. Moïsi stated that these emotions "are closely linked with the notion of confidence, which is the defining factor in how nations and people address the challenges they face as well as how they relate to one another" (Moïsi, 2010, p. 5).

First, I wish to grab the emotion of hope, which, as Moïsi argues, "is about economic and social empowerment, and its chief dwelling place [today] is in the East." (Moïsi, 2010, p. 31). This seems to be a recurring state, then, as it used to characterise the East in the late 1950s and early 1960s, when, in the post-Bandung years, after the institutionalization of non-alignment in the form of the Non-Aligned Movement (NAM) at the Belgrade Conference in September 1961, countries of the region strived for policies along some clearly defined common denominators, including the eradication of unequal economic development in the world. Lorenz Lüthi is right in emphasizing that, "Through [such] international cooperation, the members of the NonAligned Movement, particularly the dominant countries - Yugoslavia, Egypt, Indonesia (initially), and India (later on) - wanted to increase their influence in international affairs." (Lühti, 2016, p. 99). This is exactly the focal item of our geopolitical investigation as we look at the place and role of the NAM, as well as the potential alternative its allied countries intended to present within the global system.

During the 60 years of its existence, the NAM did present many achievements and delivered or contributed to the successful execution of 
crucial tasks, including the eradication of the "classical form of colonialism, [or being] instrumental in bringing about the end of apartheid in South Rhodesia and South Africa, [but also taking part in] the beginning of the North-South dialogue." (Sen, 2005, p. 133). The movement consistently articulated the importance of "the right to development and sovereignty of the State over its natural resources" (Ibid), which have become cornerstones of world politics ever since. From a geopolitical perspective, natural resources (wealth) have always been subject to scramble, and to be able to utilize them for the sake of the development of the given state, right (good) governance needs to be attached. The prerequisite to this obviously is sovereignty, which surely is not sufficient as long as the practice of patronage and rent-seeking in numerous instances narrows the circle of beneficiaries to the governing (corrupt) elite. In addition, as Paul Collier explains, "resource rents gradually erode checks and balances" (Collier, 2008 , p. 46), therefore, it is of paramount importance to improve the performance of the government for the wider societal good. In the multivector polycentric system of 2021, the Non-Aligned Movement remains a loud advocate in particular for the developing countries to first and foremost get hold of their own resources.

With their ascent sixty years ago in Belgrade, the non-aligned countries created new dynamics in the international political and economic landscape, which during the 1950s was largely overwhelmed by the security nexus of the two competing blocs of East and West. As Marianne Marchand underscored, in the context of North-South relations, "the South collectively attempted to define its relationship with the North around key economic issues." (Marchand, 1994, p. 289). Their proposed New International Economic Order (NIEO) sought a restructured arena with newly defined processes to respond to the needs of the then Third World. Southern countries "focused primarily on the areas of trade, resource transfer, and the international financial system" (Marchand, 1994, p. 292), in particular, in a period when the Bretton Woods system dominated by the U.S. was collapsing. This restructuring was meant to be, as written in the Brandt Report, "a positive process", in light of the "mutual interest of North and South" (Brandt et al., 1980, p. 35). However, due to several changes in the international system, including the "outbreak of the Third World debt crisis, the quest for a new international economic order came to a dead end." (Marchand, 1994, p. 293). This, unfortunately, provided the ground for emotions such as humiliation, despair, and fears about the future to get strengthened across the South. According to Moïsi, humiliation can "reinforce the instinct of competition. It gives energy and whets the appetite. 
[...]. To put it in another way, for humiliation to be "good humiliation" requires the least trust and favourable circumstances, such as a reasonably promising political and economic context and a national leadership up to the task." (Moïsi, 2010, p. 57). And we must not forget that gaining independence in the 1950s and 1960s came along with responsibilities for countries of the South. As Soekarno already stated at the Bandung Conference, "We have heavy responsibilities to ourselves, and to the world, and to the yet unborn generations. [...] The responsibilities and burdens, the rights and duties and privileges of independence must be seen as part of the ethical and moral content of independence." (Soekarno in Kahin, 1955, p. 41) On this ground, for the NAM and the Global South, the ending of the Cold War presented several new geopolitical considerations, which basically drove their countries into the formulation of new strategies.

\section{The NAM in the post-Cold War era: New geopolitical realities and considerations}

After the collapse of the Soviet Union and the dissolution of the Eastern Bloc, first, the international community had the feeling to experience a "unipolar moment", but gradually had started witnessing the "emergence of a more multipolar world" (Smith, 2012, p. 52), with the United States of America as undoubtedly still "by far the most powerful state on the face of the earth" (Mearsheimer, 2006, p. 113), and with an increasing number of emerging powers exerting a growing influence in the global arena. Numerous centres of gravity started to rise. As Sally Morphet suggested, "the Movement instituted a new strategy of integration in the world in order not to be left out from the mainstream of economic and technological development. Instead of the unsuccessful concept of the New International Economic Order, priority was given to various forms of regional linkages with developing countries." (Morphet, 2004, p. 528). This resonated well with what Samir Amin mentioned as one of the new forms of globalization, saying that "the Bandung project for Asia and Africa inscribed the industrialization of these countries in a newly negotiated and revised global interdependence." (Amin, 2011, p. 102). Today's international context, according to Giovanni Grevi, is best described as interpolar with the moment when "major global and regional powers cooperate to manage deepening interdependence, and build a viable and effective multilateral order." (Grevi, 2009 , p. 7). In a previous publication (Tarrósy, 2015a), I had already posed the question: Is there a chance for a newly defined (or rather re-confirmed) framework of solidarity and collaboration among Asian and African states 
to get more attention and voice in this interpolar pragmatic globalism? How much can the "Spirit of Bandung" contribute to the rise of Asian entities in Africa, and how much African agency can get strengthened via the special Afro-Asian relationship and its New Asian-African Strategic Partnership (NAASP), for instance? All these in light of the notion of hope, one of the emotions on the innovative geopolitical map drawn by Dominique Moïsi. Many have argued that with the end of the bipolar setting, the Non-Aligned Movement lost its relevance. Keethaponcalan stresses that "many of the economic issues of the NAM states, despite the organisation's intervention to remedy them, still remain unresolved." (Keethaponcalan, 2016, p.3), such as external debt, for instance, therefore, to continue with the NAM in our $21^{\text {st }}$-century global system should be re-confirmed. I agree with Morphet that "The NAM still exists and has adapted to the end of the Cold War by seeking more pragmatic and ad hoc partnerships" (Morphet, 2004, p. 528) via an issue-based approach. This is also confirmed by Fall, who underscores that "Most of the NAM's agenda and its demands are still relevant today notably: resisting the military control over the planet, advocating national and international policies for a more equitable management of resources for all people, safeguarding the rights of nations to choose their own independent development while ensuring peace and solidarity amongst nations." (Fall, 2015, p. 307). From this perspective, the latest NAM Summit in Baku (October 25-26, 2019) strengthened the standpoint of the organisation that there is a constant "need for the international community, in particular the NAM Member States, to collectively redress situations [of global nature] in accordance with the UN Charter and the principles of international law" (NAM, 2019, p. 7). From a global governance aspect, it has been crucial that since the end of the bipolar world, the dominant actors of the international system have gradually acknowledged the demand of the Global South - in line with what the NAM has always been standing for - to be able to get on the leading bodies of the multilateral organisations, therefore, to be provided with a more sophisticated articulation of their voice. We saw the ascending of the developing and emerging countries of the Global South in successfully nominating experienced experts to lead these organisations - such as in the case of the World Health Organisation (WHO), as of today, led by Dr Tedros Adhamon Ghebreyesus as directorgeneral, or the World Trade Organisation (WTO), led by Dr Ngozi OkonjoIweala as director-general since March 1, 2021. At the same time, Hennie Strydom makes a valid critical point about the responsibilities of these states (too), underlining that if "some members [of the NAM] in a multi-lateral arrangement remain internally weak and dysfunctional", that may hamper 
the "strategic interests of the members, individually or collectively" (Strydom, 2007, p. 47). Therefore, the constant effort to improve governance is a prerequisite to position the given country and the organisation better, thus, "there is a case made out for domestic reforms within [the respective] Members States first, before institutional reform at the international level will have the desired effects" (Ibid). Also, from this perspective on governance, NAM summits and high-level meetings continue to take place and the promotion of South-South cooperation has been put high on the political agendas all across the landscape. As Lee confirms, "In addition to the NAM, the Group of 77 - established within the UN in 1964 to aggregate the interests of developing countries - has since enlarged to include 134 countries. The NAM itself continues [...] to provide a forum for leaders and nation-states in Africa, Asia, and Latin America." (Lee, 2010, p. 18). In 2021, the number of members counts this 134 . How to position, re-position themselves in the global system of today, together with how to tackle global issues of insecurity and inequality, still offer sufficient ammunition for the Movement and the Global South to keep the spirit alive - obviously, in a revamped and reargued manner, as we acknowledge that with the end of the bipolar era, the "Bandung Spirit" lost its relevance from a political point of view.

Bandung 1955 and Belgrade 1961 undoubtedly resulted in some fundamental items and actors for the international system voiced more accurately and strongly under the umbrella of the "third way". Panchali Sen suggests that "In formulating its agenda for the future, the Movement should incorporate in it both its traditional and emerging goals and objectives and should also take cognizance of other issues and priorities on the international agenda." (Sen, 2005, p. 135). Among these, we find human rights, sustainable growth and development, global trade, debt relief, global peace, and social justice, to name some major items. A voice of the South representing a southern way, if you wish, over all these globally significant issues (basically, all of them are of global nature) articulated by countries aligned, however, still with the "spirits" of Bandung and Belgrade, is ever so needed. As I wrote in an article in the year of the $50^{\text {th }}$ anniversary of the Bandung conference (Tarrósy, 2005), third-way politics, or politics of the former Third World successfully influenced the thematic setting of the global agenda already in the first years of the new Millennium. Today, in 2021, North-South relations and the issues connected with the development of countries of the South have become one of the main inertia systems of our global world, and in formulating potential answers to global challenges, it is unimaginable that Southern views and demands, for example, the 
opinions and suggestions put forward by the non-aligned in the UN, are not taken into account per se. This leads us to the obvious conclusion that there is a need, ever-increasing, for such southern dialogue and cooperation, along the traditional network of non-alignment, in the sense of alliance formation and concerted efforts, and coupled with what Jazić proposes, "a fight for multilateralism, the central role of the UN and its Millennium programs [...] make the existence of the NAM no less necessary than before." (Jazić, 2005, p. 66). I still think that to allow this third way, or better to say, southern way to find proper solutions to challenges of global nature - such as the rise of transnational terrorism, fulfilling the Sustainable Development Goals (SDGs), international migration, or the vulnerabilities of financial markets - unanimous, clear and strict reforms must be carried out by the respective countries. All these need again concerted efforts of the members of the NAM.

\section{New institutionalized processes in the making - The importance of the Baku Summit of 2019}

Already the $60^{\text {th }}$-anniversary Bandung Conference in April 2015 produced some re-encouraging rhetoric. Indonesian President Joko 'Jokowi' Widodo (having assumed office in October 2014) boldly declared before closing the conference: "This is [the] revival voice of Asian-African nations that cannot be replaced by anyone." (Parameswaran, 2015). Under the motto "Strengthening South-South Cooperation to Promote World Peace and Prosperity", one main objective was to make a commitment to the "Declaration on Reinvigorating the New Asian-African Strategic Partnership", which basically reaffirmed support for the New Asian-African

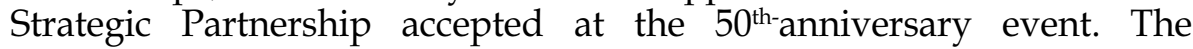
commitment to foster a "stronger, more inclusive and sustainable" partnership was again stated. However, when hearing such optimistic tones, also presented in the Declaration, it is better to stay critical, as does Ian Taylor in his book Africa Rising? BRICS - Diversifying Dependency, which rather raises attention about the extended group of entities that - as external forces - create more dependent linkages, for instance, for African actors. Taking trade as a major connecting thread, Taylor points out that the structures of emerging countries with Africa "do not exhibit any exceptionalism and are comparable to the relationships established by the capitalist core since the colonial period." (Taylor, 2014, p. 147). Taylor also emphasizes that there are obvious opportunities for African states in diversifying their relations with all those "hungry for" natural resources and 
new markets if the African agency can take control of its own resources. He also quotes Amilcar Cabral underscoring the "starting point for any true rise of Africa": "national liberation takes place when, and only when, national productive forces are completely free of all kinds of foreign domination." (Cabral, 1979, in: Ibid, p. 160). To be able to produce a new political vision and all the necessary capacities for something "different" though, signatories of the Declaration want to stick to the Spirit of Bandung and African-Asian solidarity. They are also "committed to develop an institutionalized process of the NAASP" $(2005$, p. 5), which at the same time is not an easy aspiration as far as the intergovernmental level is concerned. The text of the Declaration goes on to say that the already existing initiatives, such as the Tokyo International Conference on African Development (TICAD), the Forum on China-Africa Cooperation (FOCAC), or the IndiaAfrica Summit Forum (IASF) will be complemented the NAASP, it is hard to see in concrete terms how such an idea can really turn into a functioning operation for the benefit of all parties involved. Kenny Dlamini is right to underline that "The establishment of NAASP promised to formalise and strengthen regional cooperation between Asia and Africa, and to open more channels for economic, social and cultural relations. However, the purpose of NAASP has yet to be realised as a multilateral framework to coordinate relations between the two continents." (Dlamini, 2019, p. 1). This is an issue for further deliberation for the entire Non-Aligned Movement. Under the chairmanship of Azerbaijan, the NAM held its $18^{\text {th }}$ summit between 25 and 26 October 2019 in Baku. "The Heads of State and Government reaffirmed and underscored the validity and relevance of the Movement's principled positions concerning the promotion and preservation of multilateralism and the multilateral process." (NAM, 2019, pp. 18-19). Such a firm belief is basic to achieve many of the goals the NAM (and the numerous other stakeholders in our interpolar setting) upholds. With regard to Moïsi's thoughts about the future, what is needed is an "enlightened dream [which] indicates the direction the world could take under the guidance of the right leaders, armed with the right principles and having at their disposal the right institutional mechanisms" (Moïsi, 2010, p. 138). In particular, to ensure human security in the international system, the NAM stresses that "the national ownership, leadership and capacity building are essential elements" (NAM, 2019, p. 19), and underscores "the need for a strengthened and scaled-up global partnership for development, based on the recognition of national leadership and ownership of development strategies" (NAM, 2019, p. 166). In their final summit document, the NAM emphasized that "international cooperation must be enhanced; including the fulfilment of 
commitments of internationally agreed official development assistance, debt relief, market access, capacity building and technical support, including technology transfer" (Ibid). As for the driving principles, the NAM firmly believes in the validity of its ten founding principles, as well as its role in the "present international juncture" deriving from their reaffirmation - as adopted at the $14^{\text {th }}$ NAM Summit in Havana, in September 2016. Based on the "respect for the political, economic, social and cultural diversity of countries and peoples", it remains crucial for the NAM that the "respect for and promotion of all human rights and fundamental freedoms for all, including the effective implementation of the right of peoples to peace and development" (NAM, 2019, p. 249.) is guaranteed in the international system. This seems to be closely associated with what Nobel-laureate Amartya Sen proposed about development, which "can be seen as a process of expanding the real freedoms that people enjoy. [...] development requires the removal of major sources of unfreedom: poverty as well as tyranny, poor economic opportunities as well as systematic social deprivation, neglect of public facilities as well as intolerance or overactivity of repressive states." (Sen, 1999, p. 3). The 5-element typology developed by Sen shows the "empirical connection that links freedoms of different kinds with one another. Political freedoms [...] help to promote economic security. Social opportunities [...] facilitate economic participation. Economic facilities [...] can help to generate personal abundance as well as public resources for social facilities. Freedoms of different kinds can strengthen one another." (Ibid, p. 11). In Baku, the NAM confirmed its commitment to human security. The Baku Summit also reaffirmed "the importance of strengthening the current institutional mechanisms for South-South Cooperation and [NAM members] expressed their support for the principles on which South-South Cooperation is based." (NAM, 2019, p. 181). The 2019 event is not only a landmark multilateral political action for the host country, Azerbaijan (especially in the expanding phase of its increasingly assertive foreign policy), but also for the changing global landscape with more emerging centres of gravity.

\section{Conclusions}

Given our initial assumptions to conclude from the work of Moïsi that, "there remain reasons for hope, [as] there is a new generation of leaders [... ], so is the increasingly important role of women, [...] [together with] economic hope" (Moïsi, 2010, p. 133). Lumumba-Kasongo makes a valid point by emphasizing that the essential political issue is "to develop first the 
state's welfarism as the foundation of African-Asian solidarity" (LumumbaKasongo, 2015, p. 16). This is what may then contribute to a new type of "appreciation" of the new type of African-Asian solidarity and partnership initiative in the $21^{\text {st }}$ century, which can serve as a reaffirmed basis for the Non-Aligned Movement in the new global arena. All the entities of the system of Afro-Asian partnership want a change envisaging a "caring Asian-African society where the people live in stability, prosperity, dignity and free from the fear of violence, oppression and injustice" (NAASP, 2005, p. 3). This looks to stay a true driving force for the coming years. The new interregional alliances and collaborations of the South-South context bearing the blessings of the "spirits of Bandung and Belgrade" can mean the way forward both in political, economic, as well as geopolitical terms. "We can define peace as the ensemble of functions, including emotions that resist war and violence. [...] humanitarian deterrence, a form of preventive medicine for the international system" (Moïsi, 2010, p. 153) may mean to the terrain of multilateral politics and activism for the Non-Aligned Movement in the unfolding multipolar setting of our century.

\section{References}

Amin, S. (2011). Global History: A View from the South. Pambazuka Press, Dakar - Bangalore.

Brandt, W. et al. (1980). North-South: A programme for survival. Report of the Independent Commission on International Development Issues, The MIT Press, Cambridge, MA.

Cabral, A. (1979). Unity and Struggle: Speeches and Writings of Amilcar Cabral, Monthly Review Press, New York.

Collier, P. (2008). The Bottom Billion. Oxford University Press, Oxford - New York.

Conversations in International Relations: Interview with John J. Mearsheimer (Part I), International Relations, 20(1), pp. 105-123.

Dlamini, K. (2019). Building Asia-Africa Cooperation: Analyzing the relevance of the New Asia-Africa Strategic Partnership (NAASP), Occasional Paper 76, Institute for Global Dialogue, retrieved from www.jstor.org/stable/resrep23048. 28 March 2021.

Fall, A. S. (2015). Towards a New Movement: Aligned TransInternationalism, in: Khudori, D. (Ed.), Bandung at 60: New Insights and Emerging Forces (pp. 307-311). Puskata Pelajar, Yogyakarta. 
Grevi, G. (2009). The interpolar world: a new scenario, Occasional Papers No. 79., European Union Institute for Security Studies, pp.1-44.

Jazić, Ž. (2005). The Non-Aligned Movement Yesterday and Today - in the Process of Globalisation: Critical View, Croatian International Relations Review, 11(38-39), pp. 59-66.

Kahin, G. M. (1956). The Asian-African Conference. Bandung, Indonesia, April 1955. Cornell University Press, Ithaca, NY.

Keethaponcala, S. I. (2016). Reshaping the Non-Aligned Movement: challenges and vision, Bandung: Journal of the Global South, 3(4), pp. 1-14.

Lee, C. J. (2010). Introduction. in: Lee, C. J. (Ed.), Making a World After Empire. The Bandung Moment and Its Political Afterlives (pp.1-42). Ohio University Press, Athens, $\mathrm{OH}$.

Lühti, L. M. (2016). The Non-Aligned Movement and the Cold War, 19611973, Journal of Cold War Studies, 18(4), pp. 98-147.

Lumumba-Kasongo, T. (2015). Rethinking the Bandung conference in an Era of 'unipolar liberal globalization' and movements toward a 'multipolar politics', Bandung: Journal of the Global South, 2(9), pp. 1-17.

Marchand, M. (1994). The Political Economy of North-South Relations. in: Stubbs, R. and Underhill, G. R. D. (Eds.), Political Economy and the Changing Global Order (pp. 289-301). Macmillan, Houndsmill-London.

Moïsi, D. (2010). The Geopolitics of Emotions. Anchor Books, New York.

Morphet, S. (2004). Multilateralism and the Non-Aligned Movement: What Is the Global South Doing and Where Is It Going?, Global Governance, 10(4), pp. 517-538.

NAASP (2005). 'Declaration on the New Asian-African Partnership', Bandung, Indonesia, 24 April 2005.

NAM (2019). Final Document of the $18^{\text {th }}$ Summit of Heads of State and Government of the Non-Aligned Movement, Baku, the Republic of Azerbaijan, 25-26 October 2019.

Parameswaran, P. (2015, April 24). Did Indonesia Revive the Asia-Africa partnership?, retrieved from: http://thediplomat.com/2015/04/didindonesia-revive-the-asia-africa-strategic-partnership/. 23 January 2021.

Sen, A. (1999). Development as Freedom. Oxford University Press, Oxford New York.

Sen, P. (2005). Non-Aligned Movement and the New World Order, Jadavpur Journal of International Relations, 9(1), pp. 133-150. 
Smith, M. A. (2012). Power in the Changing Global Order. The US, Russia and China, Polity Press, Cambridge - Malden, MA.

Strydom, H. (2007). The Non-Aligned Movement and the Reform of International Relations. in: von Bogdandy, A. and Wolfrum, R. (Eds.), Max Planck Yearbook of United Nations Law, Vol. 11. (pp. 1-46). Brill, The Netherlands.

Tarrósy, I. (2005). Need for non-alignment in our global world?: The NonAligned Movement Today and Tomorrow, Croatian International Relations Review, 11(40-41), pp. 157-163.

Tarrósy, I. (2015a). Bandung in an Interpolar Context: What 'Common Denominators' Can the New Asian-African Strategic Partnership Offer?, in: Khudori, D. (Ed.), Bandung at 60: New Insights and Emerging Forces (pp. 139-148). Puskata Pelajar, Yogyakarta.

Tarrósy, I. (2015b). Africa Rising? BRICS - Diversifying Dependency by Ian Taylor, Journal of Modern African Studies, 52(2), pp. 244-246.

Taylor, I. (2014). Africa Rising? BRICS - Diversifying Dependency. James Currey, Woodbridge - Rochester, NY. 